\title{
ORTHOPOXVIRUS NEUTRALISING ANTIBODIES in SMall cetaceans from the Southeast Pacific
}

\author{
M.-F. VAn Bressem ${ }^{1,}$, K. VAn Waerebeek ${ }^{1}$ and M. BennetT ${ }^{2}$
}

Thousands of dusky dolphins (Lagenorhynchus obscurus), long-beaked common dolphins (Delphinus capensis), common bottlenose dolphins (Tursiops truncatus) of the inshore and offshore ecotypes (Van Waerebeek et al., 1990; Sanino et al., 2005) and Burmeister's porpoises (Phocoena spinipinnis) have been caught in fisheries off Peru, handled by fishmarket workers and commercialized for consumption by local people (Van Waerebeek and Reyes, 1994; Van Waerebeek et al., 1997, 1999) at least since the 1970s. In addition, traumas caused by fishing devices including gillnets, purse-seines and harpoons, probably cause the death of unknown numbers of injured small cetaceans that manage to escape (Van Bressem et al., 2006). These mammals are commonly infected by morbilliviruses, poxviruses, papillomaviruses, herpes-like viruses and Brucella sp. (Van Bressem and Van Waerebeek, 1996; Van Bressem et al., 1994; 1996, 1998, 2001a,b) and are infested by several species of helminth parasites (Reyes and Van Waerebeek, 1995; Van Waerebeek et al., 1990, 1993). Morbilliviruses, poxviruses and Brucella sp. as well as Crassicauda sp. nematodes have the potential for significant adverse impacts on population abundance by increasing natural mortality and/or by negatively affecting reproduction (Perrin and Powers, 1980; Miller et al., 1999; Van Bressem et al., 1999, 2006; González et al., 2002;). The question arises whether heavily exploited populations such as Peru's small odontocetes may suffer a leveraged, not simply additive, impact on its conservation status through an interaction of fisheries-related sources of mortality and morbidity with natural sources. This conservation concern flags these populations as priority subjects for research. In this paper we report on a serological survey for poxvirus exposure in Peruvian cetaceans.

A previous epidemiological survey indicated that poxviruses are endemic in Peruvian populations of L. obscurus, D. capensis, T. truncatus and P. spinipinnis (Van Bressem and Van Waerebeek, 1996). Infection is characterised by pathognomonic, irregular, gray, black or yellowish, stippled lesions known as "tattoos" (Figure 1) that may occur on any part of the body but which show a preferential corporal distribution depending on the species (Van Bressem and Van Waerebeek, 1996). The virus probably induces humoral immunity that may protect calves from the disease (Smith et al., 1983; Van Bressem and Van Waerebeek, 1996). The poxviruses affecting small cetaceans from the Southeast Pacific have not yet been isolated nor characterized. Other cetacean poxviruses were recently detected in both captive cetaceans, such as Indo-Pacific bottlenose dolphins (Tursiops aduncus), and in free-ranging rough-toothed dolphins (Steno bredanensis), striped dolphins (Stenella coeruleoalba) and bottlenose dolphins (T. truncatus) from Florida. A polymerase chain reaction assay was used, targeting the DNA polymerase and DNA topoisomerase genes of members of the subfamily Chordopoxvirinae (family Poxviridae) (Bracht et al., 2006). These cetacean poxviruses belong to a new genus of Chordopoxvirinae, but have a common, most immediate ancestor with terrestrial poxviruses of the genus Orthopoxvirus (Bracht et al., 2006). The genus Orthopoxvirus includes, among others, the smallpox virus (now eradicated in humans), vaccinia virus (the smallpox vaccine of unknown origin), and cowpox virus, endemic in European wild rodents and accidentally infecting humans, cats and cattle (Hazel et al., 2000; Esposito et al., 2004). The orthopoxviruses are closely related antigenically and genetically, and extensive crossneutralisation and cross-protection occur between them (Moss, 1996).

The study reported here was carried out in 1993-1997 when very few data were available on cetacean poxviruses. On the basis of the brick-shaped morphology of cetacean poxviruses (Van Bressem et al., 1993) and the biology of Chordopoxvirinae, we hypothesized that the viruses infecting dolphins and porpoises from the Southeast Pacific may share antigens with members of the Orthopoxvirus genus.

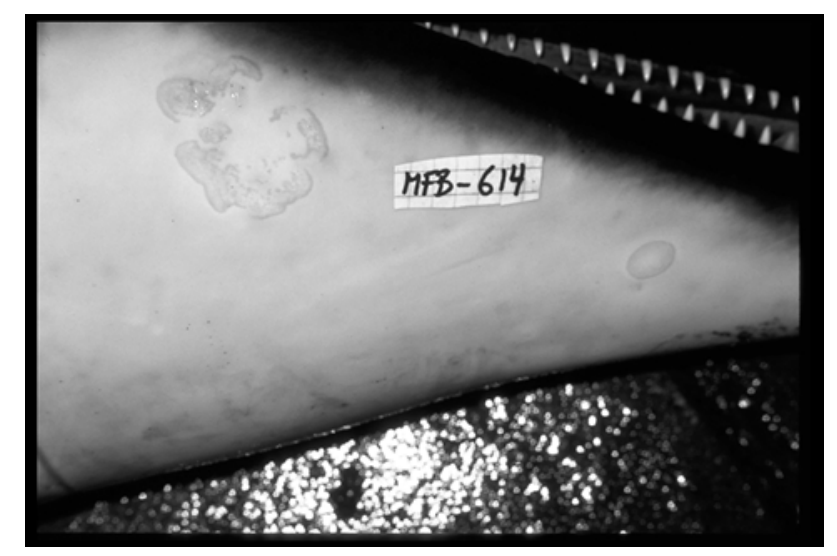

Figure 1. Tattoo lesions on the throat of a dusky dolphin (Lagenorhynchus obscurus) from Peru (MFB-614).

\footnotetext{
${ }^{1}$ Cetacean Conservation Medicine Group (CMED), CEPEC/Museo de Delfines, Pucusana, Lima 20, Peru.

${ }^{2}$ Department of Veterinary Pathology, University of Liverpool, 'Leahurst', Chester High Road, Neston, South Wirral, CH64 7TE, United Kingdom.

* Corresponding author: CMED-Europe, Waldspielplatz 11, 82319 Starnberg, Germany. E-mail: marievanbressem@yahoo.co.uk.
} 
Thus, we conducted a serological survey for the presence of orthopoxvirus neutralising antibodies in 58 small cetaceans caught off Peru in 1993-1995. We tested for cowpox virus as a representative member of the genus Orthopoxvirus that infects mammals belonging to different orders, including Artiodactyla (even-toed ungulates), which are phylogenetically closely related to cetaceans (Milinkovitch et al., 1998; Gatesy et al., 1999). Blood samples (hemolysed, except MFB-485) were collected from 6 D. capensis (all males), 27 L. obscurus (11 females, 16 males), 8 T. truncatus ( 2 inshore females, 1 offshore female, 5 offshore males) and 18 P. spinipinnis (8 females, 9 males, 1 male foetus) (Table 1). Most of these specimens were concurrently examined for tattoos in the context of an epidemiological study (Van Bressem and Van Waerebeek, 1996). All dolphins and porpoises had been dead for less than 48 hours, and were sampled in fisheries operating off Cerro Azul $\left(13^{\circ} 00^{\prime} \mathrm{S}, 76^{\circ} 30^{\prime} \mathrm{W}\right)$ and Chancay $\left(11^{\circ} 37^{\prime} \mathrm{S}, 77^{\circ} 16^{\prime} \mathrm{W}\right)$. L. obscurus and $P$. spinipinnis smaller than $160 \mathrm{~cm}$ and $140 \mathrm{~cm}$, respectively, were considered calves. Sexual maturity was determined through macroscopic examination of gonads (semen in epididymides; minimum one corpus albicans or corpus luteum in one of the ovaries), from evidence of lactation, or was inferred from the standard body length. Van Waerebeek (1992) estimated that $50 \%$ of Peruvian L. obscurus in both sexes attain sexual maturity at $175 \mathrm{~cm}$. Female and male $P$. spinipinnis reach sexual maturity on average at $155 \mathrm{~cm}$ and $160 \mathrm{~cm}$, respectively
(Reyes and Van Waerebeek, 1995).

Stocks of cowpox virus (strain L97, Gaskell et al., 1983) were produced on chorioallantoic membranes (CAM) of 12 day-old chick embryos and passaged once on Vero cells. After freeze-thawing infected cells and removing cell debris by centrifugation, the stocks were titrated and aliquots stored at $-80^{\circ} \mathrm{C}$. Before applying virus neutralising (VN) tests, the virus suspension was thawed and ultrasonicated briefly on ice to avoid clumping of virions.

Serum samples were tested for the presence of cowpox virus neutralising antibodies essentially as described previously in other mammalian species (e.g. Bennett et al., 1985; Crouch et al., 1995) using Vero cells. Briefly, all sera were diluted 10 -fold in phosphate buffer saline (PBS) with $1 \%$ foetal calf serum, complementinactivated at $56^{\circ} \mathrm{C}$ for 20 minutes and centrifuged to pellet major debris. They were further diluted three- or five-fold for the VN tests. The thirty or fifty-fold dilutions of the sera were mixed with an equal volume $(0.4 \mathrm{ml})$ of a suspension containing approximately 300 plaque forming units (pfu) $/ \mathrm{ml}$ of cowpox and incubated for 5 hours at $37^{\circ} \mathrm{C}$. An aliquot of virus at $300 \mathrm{pfu} / \mathrm{ml}$ diluted in PBS with 1\% inactivated foetal calf serum was included in a well of each set of plates to control virus activity after the incubation period. Residual infectivity was detected by inoculation of the sera-virus mixtures on Vero cell cultures in 6-well plates $(0.2 \mathrm{ml} /$ well $)$. After 1 hour incubation at $37^{\circ} \mathrm{C}$, the formation of secondary

Table 1. Distribution of maturity classes in male and female long-snouted common dolphins (D. capensis), dusky dolphins (L. obscurus), bottlenose dolphins (T. truncatus) and Burmeister's porpoises (P. spinipinnis) examined for orthopoxvirus neutralising antibodies.

\begin{tabular}{|c|c|c|c|c|c|c|c|c|c|c|}
\hline \multirow[t]{2}{*}{ SPECIES } & \multicolumn{2}{|l|}{ MATURITY } & \multicolumn{2}{|l|}{$0^{\prime}$} & \multicolumn{3}{|c|}{ 우 } & \multicolumn{3}{|c|}{ POOLED SEXES } \\
\hline & CLASS & $N$ tested & N pos & $\%$ pos & $N$ tested & N pos & $\%$ pos & $N$ tested & N pos & $\%$ pos \\
\hline \multirow[t]{2}{*}{ D. capensis } & Immature & 5 & 5 & 100 & 0 & - & - & 5 & 5 & 100 \\
\hline & Mature & 1 & 1 & 100 & 0 & - & - & 1 & 1 & 100 \\
\hline \multirow[t]{3}{*}{ L. obscurus } & Calf & 2 & 2 & 100 & 3 & 1 & 30 & 5 & 3 & 60 \\
\hline & Immature & 2 & 2 & 100 & 4 & 2 & 50 & 6 & 4 & 66.7 \\
\hline & Mature & 12 & 9 & 75 & 4 & 1 & 25 & 16 & 10 & 62.5 \\
\hline $\begin{array}{l}\text { T. truncatus } \\
\text { inshore }\end{array}$ & Immature & 0 & - & - & 2 & 2 & 100 & 2 & 2 & 100 \\
\hline T. truncatus & Immature & 3 & 3 & 100 & 0 & - & - & 3 & 3 & 100 \\
\hline offshore & Mature & 2 & 2 & 100 & 1 & 1 & 100 & 3 & 3 & 100 \\
\hline \multirow[t]{3}{*}{ P.spinipinnis } & Calf & 2 & 2 & 100 & 1 & 1 & 100 & 3 & 3 & 100 \\
\hline & Immature & 4 & 2 & 50 & 2 & 2 & 100 & 6 & 4 & 66.7 \\
\hline & Mature & 3 & 2 & 66.7 & 5 & 5 & 100 & 8 & 7 & 87.5 \\
\hline
\end{tabular}

The number $(\mathrm{N})$ of specimens tested and seropositive (pos) as well as the percentage of seropositive specimens (\% pos) are given for each subsample. 
plaques was prevented by an agarose overlay. Plaques were counted 48 hours after inoculation of the cell monolayer. Sera were considered positive when they reduced plaque formation by at least $50 \%$ at a dilution equal or higher than 1:30. The titre of 17 positive sera was further determined in the same VN test, using serial two-fold dilutions of the sera (starting at 1:20 [one serum], 1:50 [15 sera] or 1:100 [three sera]).

Cowpox virus neutralising antibodies were detected in the sera of all D. capensis and T. truncatus examined as well as in 17 of $27(63.0 \%)$ L. obscurus, and in 14 of $17^{3}$ (82.4\%) P. spinipinnis. Among 12 positive dolphins and 7 P. spinipinnis, neutralising titres ranged from 40 to over 1600 , and 50 to 200, respectively (Table 2). The high prevalence of orthopoxvirus neutralising antibodies with high titres indicates that Peruvian small cetaceans are commonly infected by poxviruses antigenically related to cowpox virus. To date, the only poxviruses microscopically encountered in these mammals are those causing the endemic and distinctive tattoo skin disease (Van Bressem and Van Waerebeek, 1996) and it is highly likely that infection by these viruses elicited the neutralising antibodies detected in this study. Furthermore, we suppose that the poxviruses infecting Peruvian small cetaceans are related to those recently detected by PCR in tattoo-like lesions in S. bredanensis and S. coeruleoalba from the North Atlantic (Bracht et al., 2006). Although these viruses probably belong to a new genus of Chordopoxvirinae, they share a common most immediate ancestor with terrestrial poxviruses (Bracht et al., 2006), which may explain the observed crossneutralization with cowpox virus. Alternatively, a true orthopoxvirus may circulate in Peruvian small cetaceans. Further investigation including PCR using the primers described by Bracht et al. (2006) and serological studies should be undertaken in these and other cetacean populations from the Southeast Pacific.

The positive dolphins and P. spinipinnis included calves as well as sexually mature and immature individuals (Tables 1 and 2). Orthopoxvirus neutralizing antibodies were not detected in the serum of a near-term foetus from a seropositive $P$. spinipinnis (JAS-50) suggesting that no antibodies were transmitted during pregnancy. The same observation was made for dolphin morbillivirus antibodies (Van Bressem et al., 2001b). The cetacean placenta is of the epitheliochorial type (Harrison, 1969) and it is thought that maternal immunoglobulins are transmitted to the offspring through colostrum as in cattle and other even-toed ungulates (Macdonald and Bosma, 1985), congruent with phylogenetic evidence (Milinkovitch et al., 1998; Gatesy et al., 1999). Thus, the antibodies detected in the sera obtained from calves L. obscurus and P. spinipinnis (Table 2) were probably of maternal origin.
A high density of tattoos was observed in three immature $D$. capensis as well as in an immature and a mature $P$. spinipinnis that showed high VN titres against cowpox virus. This may reflect a yet incomplete immune response or poxvirus immune evasion (Johnston and McFadden, 2004; Liu et al., 2005). Very high prevalence levels (over $60 \%$ ) of tattoo disease in the populations of D. capensis and P. spinipinnis studied (Van Bressem and Van Waerebeek, 1996) suggest that the poxvirus had evolved to counteract the immune response and to persist in the skin cells. The fact that tattoo skin lesions may last for months or even years and may grow very large (Geraci et al., 1979; Van Bressem and Van Waerebeek, 1996; Van Bressem et al., 2003) is also in favour of these hypotheses. Significance of differences in prevalence of cowpox neutralising antibodies between sexes was verified for $L$. obscurus and P. spinipinnis with a two-tailed Fisher's exact test (Swinscow, 1981). Seroprevalence was significantly $(\mathrm{P}=$ $0.04)$ lower in females $(36.4 \%, \mathrm{n}=11)$ than in males $(81.25 \%$, $\mathrm{n}=16)$ L. obscurus. However, low sample sizes and in particular the low number of sera from adult females may account for this difference. There was no significant sexual variation $(P=0.24)$ in seroprevalence in P. spinipinnis $(100 \%$ in 8 females, $66.7 \%$ in 9 males; Table 1 ). An epidemiological study conducted in these populations during the same period and at the same locations showed similar prevalences of tattoo lesions in male and female L. obscurus but twice as many affected males than females in $P$. spinipinnis (Van Bressem and Van Waerebeek, 1996).

Seropositivity rates were similar in both odontocete families $(75.6 \%$ in 41 Delphinidae, $82.4 \%$ in 17 Phocoenidae). However, among the immature age class the titres of neutralising antibodies were higher in the dolphins (over 1600) than in the porpoises (200), suggesting a weaker humoral response in the latter. Alternatively, the porpoises may be infected by a strain or species of poxvirus antigenically less similar to cowpox virus than the virus infecting the dolphins. These hypotheses should be further explored.

\section{Acknowledgements}

We gratefully acknowledge Joanna Alfaro-Shigueto for assistance during field work, C. McCracken for help with serological tests, Dr C. Romero for providing useful information, and Prof. P.-P. Pastoret, Dr. Nollens and Dr.Vergara-Parente for helpful comments. CMED and CEPEC were supported by the Gesellschaft zum Schutz der Meeressäugetiere, Cetacean Society International, Marine Education and Research (MER), IFAW and the Whale and Dolphin Conservation Society. MarieFrançoise Van Bressem was supported by the British Council, Air France, the 'Fonds National de la Recherche Scientifique' and the University of Liège, Belgium.

${ }^{3}$ The foetus is not considered in the statistics. 
Table 2. Presence of orthopoxvirus-specific antibodies in the sera of small cetaceans caught off Peru in 1993-1995 as detected by a virus neutralisation (VN) test using cowpox virus.

\begin{tabular}{|c|c|c|c|c|c|c|c|c|c|c|}
\hline SPECIES & CODE & & $\begin{array}{l}\text { SL } \\
\mathrm{cm})\end{array}$ & SEX & YEAR & LOCALITY & SM & $\begin{array}{l}\text { PRESENCE } \\
\text { OF TATTOOS }\end{array}$ & $\begin{array}{c}\text { DENSITY } \\
\text { OF TATTOOS }\end{array}$ & $\begin{array}{l}\text { VN ANTIBODY TITRE } \\
\text { AGAINST COWPOX }\end{array}$ \\
\hline \multicolumn{11}{|c|}{ Delphinus capensis } \\
\hline & MFB & 113 & 188.5 & 0 & 93 & Cerro Azul & $\operatorname{Imm}$ & Yes & Medium & $\geq 1600^{a}$ \\
\hline & MFB & 675 & 200.5 & 0 & 94 & Cerro Azul & Imm & Yes & High & $100^{a}$ \\
\hline & MFB & 511 & 204.5 & $\sigma^{\circ}$ & 94 & Cerro Azul & Imm & No & - & $50^{a}$ \\
\hline & MFB & 510 & 207 & 0 & 94 & Cerro Azul & Imm & Yes & High & 30 \\
\hline & MFB & 508 & 210.5 & $\sigma^{\prime}$ & 94 & Cerro Azul & Imm & Yes & Medium & $\geq 1600^{a}$ \\
\hline & MFB & 529 & 240.5 & $\sigma^{\prime}$ & 94 & Cerro Azul & Mat & No & - & $40^{\mathrm{a}}$ \\
\hline \multicolumn{11}{|c|}{ Lagenorhynchus obscurus } \\
\hline & MFB & 535 & 116,5 & 0 & 94 & Cerro Azul & Calf & No & - & $\geq 30$ \\
\hline & MFB & 514 & 130,5 & 우 & 94 & Cerro Azul & Calf & No & - & $\geq 30$ \\
\hline & MFB & 542 & 132,5 & $0^{\prime}$ & 94 & Cerro Azul & Calf & No & - & $\geq 30$ \\
\hline & MFB & 72 & 173 & 0 & 93 & Cerro Azul & [Imm] & ne & ne & $50^{\mathrm{a}}$ \\
\hline & MFB & 502 & 174 & $0^{\prime}$ & 94 & Cerro Azul & [Imm] & No & - & $\geq 50$ \\
\hline & RBC & 40 & 186 & 오 & 94 & Cerro Azul & $\mathrm{Imm}$ & No & - & $50 \mathrm{a}$ \\
\hline & MFB & 503 & 190 & 오 & 94 & Cerro Azul & Imm & No & - & $\geq 800^{a}$ \\
\hline & MFB & 71 & 185,5 & $\sigma^{\prime}$ & 93 & Cerro Azul & Mat & No & - & $\geq 30$ \\
\hline & MFB & 538 & 185,5 & 0 & 94 & Cerro Azul & Mat & No & - & $\geq 30$ \\
\hline & MFB & 75 & 186 & $\sigma^{\prime \prime}$ & 93 & Cerro Azul & [Mat] & ne & ne & $\geq 30$ \\
\hline & MFB & 111 & 186 & 0 & 93 & Cerro Azul & [Mat] & Yes & Low & $\geq 30$ \\
\hline & MFB & 506 & 187,5 & $\sigma^{\prime}$ & 94 & Cerro Azul & [Mat] & No & - & $\geq 30$ \\
\hline & MFB & 509 & 191 & $\sigma^{\prime \prime}$ & 94 & Cerro Azul & Mat & Yes & Low & $\geq 50$ \\
\hline & MFB & 543 & 191 & ㅇ & 94 & Cerro Azul & Mat & No & - & $\geq 30$ \\
\hline & MFB & 97 & 191 & $0^{\prime}$ & 93 & Cerro Azul & Mat & ne & ne & $\geq 30$ \\
\hline & MFB & 500 & 192 & $0^{\prime}$ & 94 & Cerro Azul & Mat & Yes & ne & $100^{a}$ \\
\hline & MFB & 100 & 192 & $\sigma^{\prime}$ & 93 & Cerro Azul & Mat & ne & ne & $\geq 30$ \\
\hline \multicolumn{11}{|c|}{ Tursiops truncatus (inshore) } \\
\hline & MFB & 465 & 229 & 오 & 93 & Cerro Azul & Imm & Yes & Low & $\geq 30$ \\
\hline & MFB & 485 & 253,5 & 오 & 94 & Cerro Azul & Imm & ne & ne & $\geq 50$ \\
\hline \multicolumn{11}{|c|}{ Tursiops truncatus (offshore) } \\
\hline & MFB & 533 & 262.5 & $\sigma^{\prime}$ & 94 & Cerro Azul & Imm & Yes & ne & $\geq 30$ \\
\hline & MFB & 701 & 272.5 & $\sigma^{\prime}$ & 94 & Cerro Azul & Imm & Yes & Low & $\geq 30$ \\
\hline & MFB & 616 & 295 & $\sigma^{\prime}$ & 94 & Cerro Azul & Imm & ne & ne & $\geq 800^{a}$ \\
\hline & MFB & 702 & 272 & 오 & 94 & Cerro Azul & Mat & No & - & $\geq 800^{\mathrm{a}}$ \\
\hline & MFB & 532 & 294 & $0^{\prime}$ & 94 & Cerro Azul & Mat & No & - & $\geq 30$ \\
\hline & MFB & 608 & 303.5 & $0^{\prime}$ & 94 & Cerro Azul & Mat & No & - & $50^{a}$ \\
\hline \multicolumn{11}{|c|}{ Phocoena spinipinnis } \\
\hline & JAS & 46 & 130 & $\sigma^{\prime}$ & 95 & Chancay & Calf & ne & ne & $\geq 50$ \\
\hline & MFB & 496 & 136.5 & 오 & 94 & Cerro Azul & Calf & ne & ne & $100^{a}$ \\
\hline & JAS & 44 & 135 & $\sigma^{\prime}$ & 95 & Chancay & Calf & No & - & $50^{a}$ \\
\hline & MFB & 749 & 145 & 우 & 95 & Chancay & Imm & No & - & $\geq 30$ \\
\hline & MFB & 524 & 147 & 오 & 94 & Cerro Azul & Imm & Yes & Low & $100^{a}$ \\
\hline & MFB & 479 & 151.5 & $0^{\prime}$ & 94 & Cerro Azul & {$[\mathrm{Imm}]$} & Yes & High & $200^{a}$ \\
\hline & MFB & 494 & 157 & $\sigma^{\prime}$ & 94 & Cerro Azul & {$[\mathrm{Imm}]$} & Yes & Low & $\geq 50$ \\
\hline & MFB & 493 & 153.5 & 오 & 94 & Cerro Azul & Mat & No & - & $\geq 30$ \\
\hline & MFB & 480 & 161.5 & $\sigma^{\prime}$ & 94 & Cerro Azul & [Mat] & Yes & High & $100^{a}$ \\
\hline & JAS & 43 & 163.5 & 오 & 95 & Chancay & Mat & ne & - & $\geq 30$ \\
\hline & MFB & 526 & 164 & $0^{\prime}$ & 94 & Cerro Azul & Mat & Yes & Low & $50^{a}$ \\
\hline & JAS & 50 & 169 & 오 & 95 & Chancay & Mat & Yes & ne & $50^{\mathrm{a}}$ \\
\hline & MFB & 718 & 170 & 오 & 94 & Cerro Azul & Mat & Yes & Low & $\geq 50$ \\
\hline & JAS & 48 & MAT & ㅇ & 95 & Chancay & Mat & Yes & ne & $\geq 50$ \\
\hline
\end{tabular}

Acronyms: (SL) standard body length, (SM) sexual maturity, (Mat) mature, (Imm) immature, (ne) not examined. The square brackets indicate that sexual maturity was inferred from SL, ' $a$ ' in superscript indicates that the serum was titrated. 


\section{References}

Bennett, M., Baxby, D., Gaskell, R.M., Gaskell, C.J. and Kelly, D.F. (1985) The laboratory diagnosis of Orthopoxvirus infection in the domestic cat. Journal of Small Animal Practice 26: 653-661.

Bracht, A.J., BRUdeK, R.L., EWING, R.Y., MANiRE, C.A., BUREK, K.A., Rosa, C., Beckmen, K.B., MaruniaK, J.E and Romero, C.H. (2006) Genetic identification of novel poxviruses of cetaceans and pinnipeds. Archives of Virology 151: 423-438.

Crouch, A.C., Baxby, D., McCracken, C.M., Gaskell, R.M. AND BENNETT, M. (1995) Serological evidence for the reservoir hosts of cowpox virus in British wildlife. Epidemiology and Infection 115: 185-191.

Esposito, J.J., BAXBY, D., BLACK, D.N., DALES, S., DARAI, G., DUMBELL, K.R., Granados, R.R., Joklik, W.K., McFadden, G., Moss, B., Moyer, R.W., Pickup, D.J., Robinson, A.J. And Tripathy, D.N. (2004) Family Poxviridae. In: Virus Taxonomy, ICTVdb (online).

Gaskell, R.M, Gaskell, C.J, Evans, R.J., Dennis, P.E., Bennett, A.M., Udall, N.D., Voyle, C. AND Hill, T.J. (1983) Natural and experimental pox virus-infection in the domestic cat. Veterinary Record 112: 164-170.

Gatesy, J., Milinkovitch, M.C., Waddelld, V. and Stanhope, M. (1999) Stability of cladistic relationships between Cetacea and higher level Artiodactyl taxa. Systematic Biology 48: 6-20.

Geraci, J.R., Hicks, B.D. And St Aubin, D.J. (1979) Dolphin pox: a skin disease of cetaceans. Canadian Journal of Comparative Medicine 43: 399-404.

GonzÁlez, L., Patterson, I.A., Reid, R.J., Foster, G., Barberán, M., Blasco, J.M., Kennedy, S., Howie, F.E., Godfroid, J., MacMillan, A.P., Schock, A. And Buxton, D. (2002) Chronic meningoencephalitis associated with Brucella sp. infection in live-stranded striped dolphins (Stenella coeruleoalba). Journal of Comparative Pathology 126: 147-52.

HARRISON, R.J. (1969) Reproduction and reproductive organs. Pages 253-348 in ANDERson, H.T. (Ed) The Biology of Marine Mammals, Academic Press, London.

Hazel, S.M., Bennett, M., Chantrey, J., Bown, K., Cavanagh, R., JONES, T.R., BAXBY, D. AND BEGON, M.A. (2000) A longitudinal study of an endemic disease in its wildlife reservoir: cowpox and wild rodents. Epidemiology and Infection 124: 551-62.

JoHnston, J.B. AND McFadden, G. (2004) Technical knockout: understanding poxvirus pathogenesis by selectively deleting viral immunomodulatory genes. Cellular Microbiology 6: 695-705.

Liu, L., Xu, Z., Fuhlbrigge, R.C., Peña-Cruz, V., Lieberman, J. AND Kupper, T.S. (2005). Vaccinia virus induces strong immunoregulatory cytokine production in healthy human epidermal keratinocytes: a novel strategy for immune evasion. Journal of Virology 79: 7363-7370.

Macdonald, A.A. And Bosma, A.A. (1985) Notes on placentation in the Suina. Placenta 6:83-91.

Milinkovitch, M.C., Bérubé, M. and Palsbøll, P.J. (1998) Cetaceans are highly specialized Artiodactyls. Pages 113-131 in Thewissen, J.G. (Ed) The Emergence of Whales: Evolutionary Patterns in the Origin of Cetacea. Plenum, New York.

Miller, W.G., Adams, L.G., Ficht, T.A., Cheville, N.F., Payeur, J.P., Harley, D.R., House, C. ANd Ridgway, S.H. (1999) Brucellainduced abortions and infection in bottlenose dolphins (Tursiops truncatus). Journal of Zoo and Wildife Medicine 30: 100-110.
Moss, B. (1996) Poxviridae: The viruses and their replication. Pages 2637-2671 in FIELDS, B.N., KNIPE, D.M., HowleY, P.M. et al. (Eds) Fields Virology, Third Ed., Lippincott-Raven Publishers, Philadelphia, PA.

Perrin, W.F. And Powers, J.E. (1980) Role of a nematode in natural mortality of spotted dolphins. Journal of Wildlife Management 44: 960-963.

Reyes, J.C. And VAn WAerebeeK, K. (1995). Aspects of the biology of Burmeister's porpoise from Peru. Reports of the International Whaling Commission (Special Issue 16): 349-364.

Sanino, G.P., Van Waerebeek, K., Van Bressem, M.-F. and PAstene, L.A. (2005) Preliminary mitochondrial DNA analysis on population structure in eastern South Pacific common bottlenose dolphins, Tursiops truncatus. Journal of Cetacean Research and Management 7: 65-70.

Smith, A.W., Skilling, D.E., Ridgway, S.H. And Fenner, C.A. (1983) Regression of cetacean tattoo lesions concurrent with conversion of precipitin antibody against a poxvirus. Journal of the American Veterinary Association 183: 1219-1222.

Swinscow, T.D.V. (1981) Statistics at square one. 7th edition. British Medical Association, London.

Van Bressem, M.-F. and Van Waerebeek, K. (1996) Epidemiology of poxvirus in small cetaceans from the eastern south Pacific. Marine Mammal Science 12: 371-382.

Van Bressem, M.-F., F., Gaspar, R. and Aznar, J. (2003) Epidemiology of tattoo skin disease in bottlenose dolphins (Tursiops truncatus) from the Sado estuary, Portugal. Diseases of Aquatic Organisms 56: 171-179.

Van Bressem, M.-F., Van Waerebeek, K., Reyes, J.C., Dekegel, D. AND PAstoret, P.-P. (1993) Evidence of poxvirus in dusky dolphin (Lagenorhynchus obscurus) and Burmeister's porpoise (Phocoena spinipinnis) from coastal Peru. Journal of Wildlife Diseases 29: 109-113.

Van Bressem, M.-F., Van Waerebeek, K., Garcia-Godos, A., Dekegel, D. and Pastoret, P-P. (1994) Herpes-like virus in dusky dolphins, Lagenorhynchus obscurus, from coastal Peru. Marine Mammal Science 10: 354-359.

Van Bressem, M.-F., Van Waerebeek, K., Piérard, G. and DesAINTES, C. (1996) Genital and lingual warts in small cetaceans from coastal Peru. Diseases of Aquatic Organisms 26: 1-10.

Van Bressem, M.-F., Van Waerebeek, K., Flemming, M. and BARRETT, T. (1998) Serological evidence of morbillivirus infection in small cetaceans from the Southeast Pacific. Veterinary Microbiology 2: 89-98.

VAN Bressem, M.-F., VAn WAerebeeK, K. AND RAGA, J.A. (1999) A review of virus infections of cetaceans and the potential impact of morbilliviruses, poxviruses and papillomaviruses on host population dynamics. Diseases of Aquatic Organisms 38: 53-65.

Van Bressem, M.-F., Van Waerebeek, K., Raga, J.A., Godfroid, J., BREW, S.D. AND MACMillan, A.P. (2001a) Serological evidence of Brucella species infection in odontocetes from the South Pacific and the Mediterranean. Veterinary Record 148: 657-661.

VAn Bressem, M.-F., VAn Waerebeek, K., JePson, P.D., Raga, J.A., Duignan, P.J., Nielsen, O., Di Beneditto, A.P., Siciliano, S., Ramos, R., Kant, W., Peddemors, V., Kinoshita, R., Ross, P.S., LopezFernandez, A., Evans, K., Crespo, E. and Barrett, T. (2001b) An insight into the epidemiology of dolphin morbillivirus worldwide. Veterinary Microbiology 81: 287-304. 
Van Bressem, M.-F, Van Waerebeek, K., Montes, D., Kennedy, S., Reyes, J.C., Garcia-Godos, A.I., Onton-Silva, K. AND Alfaro-Shigueto, J. (2006) Diseases, lesions and malformations in the long-beaked common dolphin (Delphinus capensis) from the Southeast Pacific. Diseases of Aquatic Organisms 68: 149-165.

Van Waerebeek, K. (1992) Population identity and general biology of the dusky dolphin Lagenorhynchus obscurus (Gray, 1828) in the Southeast Pacific. Doctoral thesis, University of Amsterdam, The Netherlands.

Van Waerebeek, K. and Reyes, J.C. (1994) Post-ban small cetacean takes off Peru: a review. Reports of the International Whaling Commission (Special Issue 15): 503-519.

Van Waerebeek K., Reyes J.C. and Alfaro J. (1993) Helminth parasites and phoronts of dusky dolphins Lagenorhynchus obscurus (Gray, 1828) from Peru. Aquatic Mammals 19: 159-169.

Van WaerebeeK, K., ReYes, J.C., Read, A.J. and McKinnon, J.S. (1990) Preliminary observations of bottlenose dolphins from the Pacific coast of South America. Pages 143-154 in Leatherwood, S. And Reeves, R.R. (Eds) The Bottlenose Dolphin, Academic Press, San Diego, CA.

Van Waerebeek, K., Van Bressem, M.-F., Felix, F., Alfaro, J., GarciaGodos, A., Chavez, L., Ontón, K., Montes, D. AND Bello, R. (1997) Mortality of dolphins and porpoises in coastal fisheries off Peru and southern Ecuador in 1994. Biological Conservation 81: 43-49.

Van Waerebeek, K., Van Bressem, M.-F., Alfaro-Shigueto, J., SAnino, G.P., Montes, D. AND OntóN, K. (1999) A preliminary analysis of recent captures of small cetaceans in Peru and Chile. Document SC/51/SM 17, International Whaling Commission, Grenada, May 1999. 